\title{
ANALISIS PEMBENTUKAN LARVA AEDES AEGYPTISp TERHADAP TEMEPHOS DEMAM BERDARAH DENGUE
}

\author{
Analysis Of The Formation Of Aedes AegytiSp Larvae Against Temephos Dengue \\ Hemorrhagic Fever In Turikale Village, Turikale District, Maros Regency \\ Stientje, Andi Yusuf, Jalil Ganesa \\ Sekolah Tinggi Ilmu Kesehatan Masyarakat Tamalatea Makassar \\ *)stientjepasenggong@gmail.com
}

\begin{abstract}
The formation of larvae from eggs turns into pupae to produce Aedes aegypti mosquitoes as vectors of diseases including Dengue Hemorrhagic Fever (DHF). Dengue hemorrhagic fever (DHF) is a disease caused by the dengue virus which is transmitted through the bite of the Aedes aegypti mosquito vector which can spread rapidly. In controlling dengue hemorrhagic fever (DHF) vectors, it is necessary to support or participate in reducing dengue cases in the Turikale Village, Turikale District, Maros Regency. The purpose of this study was to analyze the formation of Aedes aegypti larvae against temephos in DHF in Turikale Village, Turikale District, Maros Regency in the concentration range. Keywords : Larvae, Temephos, Aedes aegypti Sp
\end{abstract}

\section{ABSTRAK}

Pembentukan larva dari telur berubah menjadi pupa sampai menghasilkan nyamuk Aedes aeypti sebagai vektor penyakit diantaranya Demam Berdarah Dengue (DBD). Demam berdarah dengue (DBD) merupakan penyakit yang diakibatkan oleh virus dengue yang ditularkan melalui gigitan vektor nyamuk Aedes aegypti yang bisa menyebar secara cepat. Dalam pengendalian vektor demam berdarah dengue (DBD) diperlukan dukungan atau partisipasi warga dalam menurunkan kasus demam berdarah diwilayah Kelurahan Turikale Kecamatan Turikale Kabupaten Maros. Tujuan dari penelitian ini adalah untuk menganalisis pembentukan Larva Aedes aegypti terhadap temephos pada DBD Di Kelurahan Turikale Kecamatan Turikale Kabupaten Maros pada kisaran konsentrasi. Metode penelitian ini adalah eksperimen dengan menentukan pada kertas saring telur menempel dan selanjutnya dilakukan rearing dimana telur Aedes aegypti berubah menjadi jentik, dan di uji status kerentanan temephos terhadap larva Ae.aegypti. Penelitian dilakukan dengan uji kerentanan terhadap larva berdasarkan standar WHO (Suceptability Test). Hasil menunjukkan rata-rata kematian larva pada setiap konsentrasi $0,005 \mathrm{mg} / \mathrm{L}, 0,01 \mathrm{mg} / \mathrm{L}, 0,02 \mathrm{mg} / \mathrm{L}$ dan $0,03 \mathrm{mg} / \mathrm{L}$ menunjukkan kematian larva $100 \%$ setelah kontak dengan temephos.

Kata Kunci : Larva, Temephos, Aedes aegypti Sp

\section{PENDAHULUAN}

Vektor adalah merupakan pengantar penyakit yang bisa menularkan, memindahkan dan sebagai sumber penularan penyakit pada manusia seperti Demam Berdarah Dengue.Virus dengue merupakan penyebab terjadinya Demam berdarah, dimana virus ini berada di tubuh manusia dengan gigitan nyamuk Aedes aegypti dan termasuk vektor penular penyakit utama bagi manusia, dan merupakan wilayah untuk kelangsungan populasi agent maupun vector(Kemenkes, 2010); (Organization, 2009). Penyakit DBD pertama kali di temukan di Negera Asia, Afrika, serta Amerika Utara, pada tahun 1780 (Organization, 2004).Data dari Organisasi kesehatan dunia atau World Health Organizationv (Organization et al., 2009) sekitar2, 5 milyar penduduk dunia rentan berisiko penularan virus DBD.Sebanyak 500.000 pasien DBD harus melakukan perawatan dan kasus setiap tahun sebanyak 20 juta kasus.

Upaya yang dilakukan oleh pemerintah dalam mengatasi masalah DBD secara kuratif, dan telah sukses menurunkan kematian (CFR) untuk penderita DBD, namun pada insidensi (IR) terjadi penambahan dan juga penyebaran kasus DBD yang melebar ke pelosok daerah. Organisation Internasional
Dunia menetapkan untuk penangan DBD yang baik dengan melakukan pengendalian vector, contol pada stadium larva dan pencegahan pada stadium dewasa. Dalam mengatasi kasus DBD data lingkungan berupa tempat berkembang biaknya nyamuk Aedes aegypti, serta Maya Indeks (MI) dari kasus DBD. Analisis Maya Indeks adalah untuk mencatat suatu area yang berisiko tinggi sebagai wadah perkembang biakan (breeding site) larva Aedes aegypti. Adapun Maya Indeks dari kasus DBD menerapkan kebersihan lingkungan sekitar dan membuang wadah yang bepeluang menjadi wadah berkembang biaknya nyamuk.

Data Dinas Kesehatan Provinsi Sulawesi Selatan tahun 2020 mencatat yang terkena penyakit demam berdarah dengue (DBD) mencapai 2.166 orang sepanjang bulan januari sampai bulan Mei 2020, dari data diatas terdapat 19 orang yang meninggal dunia yang diakibatkan oleh penyakit demam berdarah dengue (DBD) diantaranya : Kabupaten Gowa 6 orang meninggal dunia, Kabupaten Enrekang 4 orang yang meninggal dunia, Kabupaten Maros terdapat 3 orang yang meninggal dunia disusul Kabupaten Soppeng 3 orang yang meninggal dunia, Je'neponto terdapat 2 orang yang meninggal dunia serta 
Jurnal Sulolipu : Media Komunikasi Sivitas Akademika dan Masyarakat

Vol. 21 No.2 2021

e-issn : 2622-6960, p-issn : 0854-624X

Kabupaten Bone terdapat 1 orang yang meninggal dunia (TP2P Dinkes Sul- Sel, 2020).

Dalam pengendalian vektor demam berdarah dengue (DBD) diperlukan partisipasi warga dalam menurunkan kasus demam berdarah didaerah Kelurahan Turikale Kecamatan Turikale. Adapun partisipasi masyarakat yaitu dengan meningkatkan pengetahuan masyarakat tentang vector penyakit DBD dan meningkatkan skill masyarakat dalam mengendalikan kasus DBD yang berkesinambungan (Trapsilowati et al., 2015).

Data Dinas kabupaten Maros pada tahun 2016 terdapat 628 kasus penyakit DBD, tahun 2017 terdapat 253 kasus dan tahun 2018 terdapat 319 kasus, dan ditahun 2019 kasus penyakit DBD sampai bulan April di Kabupaten Maros terdapat 97 kasus DBD, diantaranya yang meninggal dunia sebanyak 2 orang (data Dinkes Maros, 2019), dan tahun 2020 terdapat 74 kasus DBD yang terjadi di Kelurahan Turikale Kecamatan Turikale Kabupaten Maros. Dari data diatas terjadi penurunan kasus DBD di Kelurahan Turikale Kecamatan Turikale Kabupaten Maros.

\section{TUJUAN PENELITIAN}

Mengetahui Analisis Pembentukan Larva Aedes aegypti Terhadap Temephos Pada DBD Di Kelurahan Turikale Kecamatan Turikale Kabupaten Maros.

\section{METODE}

Jenis penelitian yang digunakan adalah penelitian eksprimen dengan pendekatan deskriptif sehingga dapat diketahui status resitensi larva Aedes aegypti di Kelurahan Turikale Kecamatan Turikale Kabupaten Maros. Dalam pemasangan ovitrap ada 17 rumah yang diletakkan Untuk tempat bertelurnya Ae.Aegypti. Sampel telur yang diperoleh dari hasil observasi 8 rumah pada yang endemis DBD di Kelurahan Turikale Kec.Turikale Kabupaten Maros. Dari pemasangan ovitrap ini dilakukan didalam rumah dan diluar rumah dan pemeriksaan dilakukan di laboratorium vektor Kampus Kesehatan Lingkungan Poltekkes Makassar.

Populasi penelitian adalah telur Ae. Aegypti yang menempel pada Kertas saring di gunakan prosedur rearing atau Pembentukan larva Ae. Aegypti yang resisten pada larvasida temephos. Sampel dalam penelitia ini adalah jentik Ae. aegypti instar tiga yang sudah resisten pada larvasida temephos yang di pakai pada uji Susceptibillity temephos dari beberapaa kontainer. Untuk menetukan status kerentanan temefos terhadap larva Ae.aegypti ditafsirkan mengikuti panduan WHO (1975), yang terbagi ke dalam kategori: 1. Resisten apabila kematian kurang dari $80 \%$, 2. Toleran apabila kematian $80-97 \%$, 3 . Rentan apabila kematian 98-100\% Jika tingkat kematian5 - 20\%, maka dikoreksi melalui formula abbot, namun apabila tingkat kematian larva $>20 \%$, maka semua proses yang telah dilalui gagal dan diulang kembali dari awal.

\section{HASIL}

Hasil penelitian tentang analisis pembentukan larva Aedes aegypty terhadap penggunaan themofos pada DBD di Kelurahan Turikale Kecamatan Turikale Kabupaten Maros yang dilakukan mulai tanggal 29 Maret 2021 sampai dengan 10 Mei 2021 dengan beberapa rangkaian kegiatan penelitian sebagai berikut :

Pelaksanaan uji resistensi dilakukan sebanyak tiga kali pelaksanaan ditiap konsentrasi dan waktu pelaksanaan yang berbeda hal ini ,005 mg/l, 0,01 mg/l, 0,02 $\mathrm{mg} / \mathrm{l}$, dan $0,03 \mathrm{mg} / \mathrm{l}$ dilakukan untuk mendapatkan gambaran yang lebih detail dan menyesuaikan kondisi pada lokasi penelitian dengan konsentrasi bahan aktif themofos 0 dapat dilihat pada table berikut : Hasil pelaksanaan uji pada konsentrasi temophos 0,005 mg/l, 0,01 mg/l, 0,02 mg/l dan $0,03 \mathrm{mg} / \mathrm{l}$ pada larva Aedes aegypti menunjukkan presntase kematian secara total yang menunjukkan status larva yang masih rentan, dengan kondisi suhu dan $\mathrm{pH}$ yang masih normal.

\section{PEMBAHASAN}

1. Status Resistensi Larva Aedes aegypti sp Terhadap Larvasida Temephos Konsentrasi 0,005 mg/L.

Berdasarkan uji Susceptybiliti yang dilakukan sebanyak tiga kali terhadap larva Ae. Aegypti dapat dilihat bahwa kemampuan dan sifat bahan aktif pada temephos yang digunakan pada daerah endemis di Kelurahan Turikale Kecamatan Turikale Kabupaten Maros, selamakurun waktu lima tahun menunjukkan hasil uji status vector berdasarkan standar WHO 1975 serta standar Peraturan Permenkes No. 50 tahun 2017 bahwa status larva/jentik terhadap abate 1GR (temefos) masih rentan. pada table 1, uji status kerentanan larva terhadap temephos pada 
konsentrasi $0,005 \mathrm{mg} / \mathrm{L}$ yang diujikan pada larva instar tiga, di peroleh bahwa pada setiap pengulangan yaitu pertama sampai pengulangan ketiga ditemukan adanya kematian larva. Adapun persentase kematian larva terhadap temephos selama pengamatan 24 jam adalah $100 \%$.

Berdasarkan kondisi sebagai daerah endemis DBD dan upaya pengendalian yang telah dilakukan dengan menggunakan larvasida dalam kurung waktu tertentu menjadi alasan dan dasar pertimbangan untuk mengetahui kondisi vektor aedes aegypti terhadap penggunaan temefos, sehingga diharapkan dengan hasil yang diperoleh dapat dijadikan dasar dalam menentukan teknik dan upaya pengendalian selanjutnya.

Uji kerentanan yang telah dilaksanakan dengan berbagai konsentrasi yang berbeda yaitu konsentrasi $0,005 \mathrm{mg} / \mathrm{l}$, yang dikontakkan menunjukkan bahwa kondisi larva setelah penambahan konsentrasi berada pada daaerah endemis yang dalam artian masih dalam ketegori rentan terhadap penambahan atau penggunaan bahan temefos dan belum menimbulkan respon resisten terhadap jumlah dari varias konsentrasi temefos.

Pada status rentan dalam pelaksanaan penelitian ini dipengaruhi oleh kemapuan bahan aktif temephos dalam mematikan larva Aedes, dimana ada beberapa factor yang berpengaruh didalam mematikan larva/jentik antara lain : waktu pemaparan, jenis dan kondisi jentik/larva yang digunakan, kondisi lingkungan $\mathrm{pH}$ air dalam pelaksanaan pengujian, suhu lingkungan, dan kelembaban).

\section{Status Resistensi Larva Aedes aegypti} sp Terhadap Larvasida Temephos Konsentrasi $0,01 \mathrm{mg} / \mathrm{L}$.

Dari hasil identifikasi,

dilakukan uji status kerentanan larva terhadap temephos dengan menggunakan konsentrasi $0,01 \mathrm{mg} / \mathrm{L}$. Uji hasil dengan konsetrasi tersebut diperoleh kamtian larva pada setiap pengamatan waktu selama 24 jam, diperoleh hasil yang berbeda namun kesemua larva dapat mati dengan kontak temephos pada konsentrasi tersebut. persentase kematian larva uji pada konsentrasi $0,01 \mathrm{mg} / \mathrm{L}$ selama pengamatan 24 jam adalah 100\% kematian larva.

Cara kerja abate pada larva jentik adalah menghambat kinerja enzim dalam pembentukan sel saraf dari larva atau jentik serangga tersebut, dengan kondisi dan kemampuan abate ini, jentik nyamuk tidak dapat berkembang bahkan langsung mati sesaat setelah menelan atau kontak dengan bubuk abate yang ditaburkan pada habitat mereka. Selain itu abate juga memiliki efek residu yang bekerja untuk menghalau kembalinya nyamuk atau serangga selama beberapa minggu setelah pemakaian.

Penggunaan abate sebagai larvasida juga memiliki kelemahan, jika dosis abate ditingkatkan terus menerus maka akan membahayakan kesehatan masyarakat dan kesehatan lingkungan. Golongan organofosfat ini bila ditingkatkan dosisnya maka akan menimbulkan toksisitas tinggi baik pada jentik nyamuk Aedes spp dan bagi kita yang apabila kena paparan langsung dari abate, seperi tertelan akan menimbulkan keracunan

Proses masuknya bahan aktif temefos kedalam jaringan tubuh larva jentik aedes agepti terajdinya secara cepat menginagt sifat dari bahan kimia temefos yang bersifat nonsistemik, selain itu dampak keracunan fosfat organik pada insect khususnya tahap larva memberi dampak pada kondisi lemast ketidak berdayaan, hipereksitasi, tremor dan konvulsi, kemudian kelumpuhan otot (paralisa), selain itu kondisi yang terjadi pada lingkungan air yang telah terkontaminasi bahan temefos memberi dampak keterbatasan pada larva nyamuk dalam memperoleh ketersedian oksigen bebas bahan residu temefos sehingga memicu dan mendukung terjadinya ganguan dan kematian pada larva Aedes aegypti.

\section{Status Resistensi Larva Aedes aegypti sp Terhadap Larvasida Temephos Konsentrasi $0,02 \mathrm{mg} / \mathrm{L}$.}

Uji susceptybiliti yang dilakukan dilaboratorium dengan konsentrasi $0,02 \mathrm{mg} / \mathrm{L}$ ini diperoleh hasil pengujian larva terhadap temephos pada setiap pengulangan di peroleh kematian larva yang berbeda namun secara keseluruhan dari pengamatan setiap 8 jam kematian seluruh larva. Persentase kamtian larva setelah kontak dengan temephos $0,02 \mathrm{mg} / \mathrm{L}$ adalah $100 \%$.

Terjadinya kematian larva aedes aegypti $100 \%$ pada pelaksanaan uji resistensi adalah sebuah kewajaran 
dan lumrah jika didasarkan pada kebiasaan dan perilaku jentik/larva Aedes aegypti biasa bergerak-gerak lincah dan aktif, dengan memperlihatkan gerakan-gerakan naik ke permukaan air dan turun kedasar wadah secara berulang, Larva mengambil makanan di dasar wadah, oleh karena itu larva Aedes aegypti disebut pemakan makanan di dasar atau yang sering disebut bottomfeeder.

\section{Status Resistensi Larva Aedes aegypti sp Terhadap Larvasida Temephos Konsentrasi $0,03 \mathrm{mg} / \mathrm{L}$.}

Dari hasil status resistensi larva terhadap temephos pada konsentrasi $0,03 \mathrm{mg} / \mathrm{L}$ pada pengamatan setiap $8 \mathrm{jam}$ diperoleh hasil kematian larva dibawah 10 kematian larva. Dalam uji ini dilakukan penulangan sebanyak 3 kali replikasi, sebagaimana kita ketahui bahwa pemakaian larvasida temephos yang termasuk dalam golongan organofhosfat yang apabila masuk kedalam tubuh serangga dapat bersifat menghambat enzim cholinesterase yang ada dalam tubuh serangga. Enzim ini dapat menimbulkan gangguanuan pada aktifitas syaraf pada serangga. Hasil penelitian dengan konsentrasi temephos $0,03 \mathrm{mg} / \mathrm{L}$ pada larva Ae. Aegypti diperoleh persentase $100 \%$ kematian larva.

$$
\text { Kelebihan penggunaan }
$$

temephos bila digunakan dengan benar antara lain; sangat efektif untuk mengendalikan semua jentik nyamuk, merupakan pertahanan pertama terhadap penyakit yang disebabkan oleh nyamuk, tidak menimbulkan residu dan daya racun rendah bila digunakan sesuai petunjuk.

Penelitian ini berbeda dengan penelitian yang pernah dilakukan di wilayah Kota Palu bahwa penggunaan temephos dapat meningkatkan Angka Bebas jentik (ABJ), serta memiliki resiko lebih kecil terhadap kejadian DBD. Penggunaan themepos merupakan salah satu penerapan Pemberantasan Sarang Nyamuk (PSN) di rumah tangga. Sebuah studi di Bogor menunjukkan bahwa penerapan PSN secara mandiri di rumah tangga terkait dengan keberadaan jentik. Tidak ditemukannya hubungan penggunaan temephos terhadap kepadatan jentik disebabkan oleh jenis kontainer yang paling banyak ditemukan positif jentik adalah ember, sedangkan temephos biasanya digunakan pada tempat penampungan air yang besar seperti bak mandi maupun penampungan air lainnya. Selain itu penggunaan temephos dengan dosis yang tidak sesuai dengan volume air turut pula berpengaruh terhadap populasi vektor. pada studi ini . Jenis kontainer, Bila dosis terlalu rendah dapat menyebabkan percepatan terjadinya resistensi terhadap jentik vektor terhadap temephos, sedangkan bila dosis terlalu tinggi akan tidak ekonomis dan mungkin mengganggu miro lingkungan.

Pada penelitian ini anggota keluarga yang paling berperan dalam pemanfaatan temephos adalah ibu rumah tangga. Penelitian ini serupa dengan penlitian yang di lakukan di Sendangmulyo menyatakan ibu rumah tangga berusaha menjaga kebersihan lingkungan terutama penampungan air dari jentik nyamuk Ae. Aegypti dengan cara menguras serta memberikan bubuk temephos. Dari segi kesehatan, ibu rumah tangga lebih perhatian dibandingkan dengan laki-laki mengenai DBD karena dapat memberikan dampak perekonomian, emosi dan masalah kesehatan keluarga.

\section{KESIMPULAN}

1. Berdasarkan hasil penelitian yang di peroleh dari uji Susceptybiliti, dapat disimpulkan bahwa pemanfaatan temefos pada konsentrasi $0,005 \mathrm{mg} / \mathrm{L}$ sebagai larvasida untuk pengendalian larva Ae. aegypti masih dalam kategori rentan di Kelurahan Turikale, Kecamatan Turikale Kabupaten Maros.

2. Berdasarkan hasil penelitian yang diperoleh dari uji susceptybiliti yang telah dilakukan dapat disimpulkan bahwa status kerentanan larva Ae.aegypti terhadap temephos pada konsentrasi $0,01 \mathrm{mg} / \mathrm{L}$ sebagai larvasida digunakan dalam pengendalian Ae. Aegypti masih dalam ketegori rentan di Kelurahan Turikale Kecamatan Turikale Kabupaten Maros.

3. Berdasarkan hasil penelitian yang diperoleh dari uji susceptybiliti yang telah dilakukan dapat disimpulkan bahwa status kerentanan larva Ae.aegypti terhadap temephos pada konsentrasi $0,02 \mathrm{mg} / \mathrm{L}$ sebagai larvasida yang digunakan dalam pengendalian Ae. Aegypti masih dalam ketegori rentan di Kelurahan Turikale Kecamatan Turikale 
Jurnal Sulolipu : Media Komunikasi Sivitas Akademika dan Masyarakat

Vol. 21 No.2 2021

e-issn : 2622-6960, p-issn : 0854-624X

Kabupaten Maros.Dan konsentrasi ini yang dianjurkan oleh WHO Tahun 1975.

4. Berdasarkan hasil penelitian yang diperoleh dari uji susceptybiliti yang telah dilakukan dapat disimpulkan bahwa status kerentanan larva Ae.aegypti terhadap temephos pada konsentrasi $0,03 \mathrm{mg} / \mathrm{L}$ sebagai larvasida digunakan dalam pengendalian Ae. Aegypti masih dalam ketegori rentan di Kelurahan Turikale Kecamatan Turikale Kabupaten Maros.

\section{SARAN}

1. Pelaksanaan uji hendaknya dilakukan untuk mengetahui status kelayakan pengguanaan larvasida, untuk mendapatkan hasil yang lebih baik dan pelaksanaan uji dilakukan secara menyeluruh di seluruh kecamatan.

2. Bagi petugas kesehatan diharapkan dapat penyampaikan cara penggunaan temefos pada penampungan air masyrakat agar mendapatkan hasil yang efektif.
3. Untuk penelitian selanjutnya diharapkan bisa meneliti jenis spesies vector DBD seperti aedes albopictus terhadap penggunaan temefos.

4. Memaksimalkan pemberdayaan masyarakat melauai PSN dan 3M dimaksimalkan, penerapan atau implementasi dari beberapa kajian penelitian yang telah terbukti serta dukungan penuh dari pemerintah, kesadaran dan kebersamaan masyarakat dalam berperan aktif menangani masalah DBD di kabupaten Maros.

\section{UCAPAN TERIMA KASIH}

Ucapan terimakasih disampaikan kepada Poltekkes Kemenkes Makassar dalam hal ini Jurusan Kesehatan Lingkungan atas tempat penelitian. Ucapan terima kasih kepada seluruh staf Kelurahan Turikale atas bantuan tenaga, serta mahasiswa Jurusan Kesling yang membantu dalam penelitian ini.

\section{DAFTAR PUSTAKA}

Anggraeni, D. S. (2010). Stop Demam Berdarah Dengue. Bogor: Bogor Publ House.

Beaver, R. A., Wilding, N., Collins, N., Hammond, P., \& Webber, J. (1989). Insect-fungus relationships in the bark and ambrosia beetles. Insect-Fungus Interactions, 121, 143.

Bestari, R. S., \& Siahaan, P. P. (2018). Hubungan Tingkat Pengetahuan dan Perilaku Mahasiswa Tentang Pemberantasan Sarang Nyamuk (PSN) Demam Berdarah Dengue (DBD) Terhadap Keberadaan Jentik Aedes Aegypti. Biomedika, 10(1), 1-5.

Cavalcanti, L. P. de G., Mota, L. A. M., Lustosa, G. P., Fortes, M. C., Mota, D. A. M., Lima, A. A. B., Coelho, I. C. B., \& Mourão, M. P. G. (2014). Evaluation of the WHO classification of dengue disease severity during an epidemic in 2011 in the state of Ceará, Brazil. Memorias Do Instituto Oswaldo Cruz, 109(1), 93-98.

DepKes, R. I. (2005). Pencegahan dan pemberantasan demam berdarah dengue di Indonesia. Jakarta: Direktorat Jendral PPP-PPL.

DEPKES, R. I. (1999). Paradigma Sehat Menuju Indonesia Sehat 2010. Depkes, Jakarta.

Ginanjar, G. (2008). Demam berdarah. PT Mizan Publika.

Hadi, A. C. S., Soedarto, H., \& Mansoben, J. (1995). Kumpulan sari hasil penelitian Universitas Cenderawasih. [Unit Pelaksana Teknis Perpustakaan], Universitas Cenderawasih.

Harié, G., Samat, A., Guglielmetti, R., De Keukeleire, D., Saeyens, W., \& Van Parys, I. (1997). Photochromic Behaviour of Bis [4-(N, N-dimethylamino) phenyl]-substituted $3 \mathrm{H}$-Naphtho [2, 1-b] pyran and $2 \mathrm{H}-1$-Benzopyran. Tetrahedron Letters, 38(17), 3075-3078.

Health, W. H. O. D. of M., Abuse, S., Organization, W. H., Health, W. H. O. D. of M., Health, S. A. M., Evidence, W. H. O. M. H., \& Team, R. (2005). Mental health atlas 2005. World Health Organization.

Hoedojo, R., \& Sungkar, S. (1993). Parasitologi Kedokteran. Edisi Ke-2. Fakultas Kedokteran Universitas Indonesia. Jakarta.

Ikawati, B., Sunaryo, S., \& Widiastuti, D. (2015). Peta status kerentanan Aedes aegypti (Linn.) terhadap insektisida cypermethrin dan malathion di Jawa Tengah. Aspirator Journal of Vector-Borne Diseases, 7(1), 23-28.

Jumar, F. A. (2000). Le commerce atlantique au Río de la Plata 1680-1778. Paris, EHESS.

Kajeguka, D. C., Kaaya, R. D., Desrochers, R., Iranpour, M., Kavishe, R. A., Mwakalinga, S., Schiøler, K. L., Alifrangis, M., Lindsay, R., \& Dibernardo, A. (2017). Mapping clusters of chikungunya and dengue transmission in northern Tanzania using disease exposure and vector data. Tanzania Journal of Health Research, 19(4). 
Jurnal Sulolipu : Media Komunikasi Sivitas Akademika dan Masyarakat

Vol. 21 No.2 2021

e-issn : 2622-6960, p-issn : 0854-624X

Kasper, L. F., \& Petrello, B. A. (1996). Responding to ESL student writing: The value of a nonjudgmental approach. Community Review, 14(5), 5-12.

KEMENKES, R. I. (2010). Pedoman pelayanan antenatal terpadu. Direktur Jenderal Bina Kesehatan Masyarakat Kementerian Kesehatan Republik Indonesia, Jakarta.

Kemkes, R. I. (2011). Modul pengendalian demam berdarah dengue. Jakarta: Dirjen P2PL Depkes RI.

Kusdarwati, R., Ratnaningtyas, A., \& Meles, D. K. (2013). Uji Aktivitas Antifungi Ekstrak Rimpang Kencur (Kaempferia galanga L.) Terhadap Saprolegnia sp. Secara In Vitro [Antifungal Activity Test Of Kaempferia galanga L. Extract To Saprolegnia sp. By In Vitro]. Jurnal IImiah Perikanan Dan Kelautan, 5(1), 23-30.

Kusuma, A. P., \& Sukendra, D. M. (2016). Analisis spasial kejadian demam berdarah dengue berdasarkan kepadatan penduduk. Unnes Journal of Public Health, 5(1), 48-56.

Lloyd, J. E., Herms, D. A., Rose, M. A., \& Van Wagoner, J. (2006). Fertilization rate and irrigation scheduling in the nursery influence growth, insect performance, and stress tolerance ofSutyzam'crabapple in the landscape. HortScience, 41(2), 442-445.

Mulyatno, K. C., Yamanaka, A., \& Konishi, E. (2012). Resistance of Aedes aegypti (L.) larvae to temephos in Surabaya, Indonesia. Southeast Asian Journal of Tropical Medicine and Public Health, 43(1), 29.

Organization, W. H. (2004). The World health report: 2004: changing history. World Health Organization.

Organization, W. H. (2009). WHO vaccine-preventable diseases: monitoring system: 2009 global summary. World Health Organization.

Organization, W. H. (2011). WHO report on the global tobacco epidemic, 2011: warning about the dangers of tobacco. Geneva: World Health Organization.

Organization, W. H., Research, S. P. for, Diseases, T. in T., Diseases, W. H. O. D. of C. of N. T., Epidemic, W. H. O., \& Alert, P. (2009). Dengue: guidelines for diagnosis, treatment, prevention and control. World Health Organization.

Ponlawat, A., Scott, J. G., \& Harrington, L. C. (2005). Insecticide susceptibility of Aedes aegypti and Aedes albopictus across Thailand. Journal of Medical Entomology, 42(5), 821-825.

Pratiwi, A. M. (2016). Daya Bunuh Air Perasan Rimpang Kunyit (Curcuma Domestica Val) Terhadap Kematian Larva Aedes Aegypti. Universitas Negeri Semarang.

Prov, D. (2014). Sulsel.(2015). Profil Kesehatan Provinsi Sulawesi Selatan.

Ridha, M. R., \& Nisa, K. (2011). Larva Aedes aegypti sudah toleran terhadap Temepos di kota Banjarbaru, Kalimantan Selatan. Vektora: Jurnal Vektor Dan Reservoir Penyakit, ^`n), 92109.

Sembel, D. T. (2009). Entomologi kedokteran.

Soedarmo, S. S. P. (1983). Demam berdarah (Dengue) pada anak. Penerbit Universitas Indonesia.

Soegijanto, S. (2004). Kumpulan makalah penyakit tropis dan infeksi di Indonesia. Airlangga University Press.

Sudoyo, A. W., Setiyohadi, B., Alwi, I., Simadibrata, M., \& Setiati, S. (2009). Buku Ajar Ilmu Penyakit Dalam Jilid II edisi V. Jakarta: Interna Publishing, 310, 1973-1982.

Sukmawati, S., Ishak, H., \& Arsin, A. A. (2018). Uji kerentanan Untuk Insektisida Malathion Dan Cypermethrine (CYF 50 ec) Terhadap Populasi Nyamuk Aedes aegypti Di Kota Makassar dan Kabupaten Barru. HIGIENE: Jurnal Kesehatan Lingkungan, 4(1), 41-47.

Supartha, I. W. (2008). Pengendalian terpadu vektor virus demam berdarah dengue, Aedes aegypti (Linn.) dan Aedes albopictus (Skuse)(Diptera: Culicidae). Penelitian IImiah, 3-6.

TAKAOKA, H., HADi, U. K., \& SIGIT, S. H. (2006). A new species of Simulium (Simulium) from Sumatra, Indonesia (Diptera: Simuliidae). Medical Entomology and Zoology, 57(1), 27-34.

Taslisia, T., Rusdji, S. R., \& Hasmiwati, H. (2018). Survei Entomologi, Maya Indeks, dan Status Kerentanan Larva Nyamuk Aedes aegypti terhadap Temephos. Jurnal Kesehatan Andalas, $7(1), 33-41$.

Trapsilowati, W., Mardihusodo, S. J., Prabandari, Y. S., \& Mardikanto, T. (2015). Partisipasi masyarakat dalam pengendalian vektor demam berdarah dengue di Kota Semarang Provinsi Jawa Tengah. Vektora: Jurnal Vektor Dan Reservoir Penyakit, 7(1), 15-22.

Zimmermann, S., Lyon, J., Bertolin, A., Jetmalani, K., King, G., \& Thamrin, C. (2015). Withinbreath resistance and reactance and short-term repeatability in two forced oscillation technique devices. Eur Respiratory Soc. 
Jurnal Sulolipu : Media Komunikasi Sivitas Akademika dan Masyarakat

Vol. 21 No.2 2021

e-issn : 2622-6960, p-issn : 0854-624X

Lampiran.

Tabel 4.1 Hasil Uji Resistensi Larva Aedes aegyptiSp Terhadap Penggunaan Temephos 0,005 mg/L Setelah 24 Jam Di Kelurahan Turikale Kecamatan Turikale Kabupaten Maros Tahun 2021

\begin{tabular}{clcccccc}
\hline No. & Perlakuan & $\begin{array}{c}\text { Jumlah } \\
\text { Jentik }\end{array}$ & $\begin{array}{c}\text { Jumlah } \\
\text { Kematian }\end{array}$ & $\begin{array}{c}\% \\
\text { Kematian } \\
\text { Jentik }\end{array}$ & $\begin{array}{c}\text { Suhu } \\
\left({ }^{\circ} \mathbf{C}\right)\end{array}$ & pH & $\begin{array}{c}\text { Status } \\
\text { Uji }\end{array}$ \\
\hline 1 & Kontrol & 20 & 0 & 0 & 29 & 7,0 & Rentan \\
2 & R.1-8.JM-1 & 20 & 3 & 15 & 29 & 7,0 & Rentan \\
3 & R.1-8.JM-2 & 20 & 8 & 40 & 29 & 7,0 & Rentan \\
4 & R.1-8.JM-3 & 20 & 9 & 45 & 29 & 7,0 & Rentan \\
5 & R.2-8.JM-1 & 20 & 4 & 20 & 29 & 7,0 & Rentan \\
6 & R.2-8.JM-2 & 20 & 9 & 45 & 29 & 7,0 & Rentan \\
7 & R.2-8.JM-3 & 20 & 7 & 35 & 28 & 7,0 & Rentan \\
8 & R.3-8.JM-1 & 20 & 5 & 25 & 29 & 7,0 & Rentan \\
9 & R.3-8.JM-2 & 20 & 8 & 40 & 29 & 7,0 & Rentan \\
10 & R.3-8.JM-3 & 20 & 7 & 35 & 29 & 7,0 & Rentan \\
\hline
\end{tabular}

Sumber : Juli 2021

Tabel 2 Hasil Uji Resistensi Larva Aedes aegyptiSp Terhadap Penggunaan Temephos $0,01 \mathrm{mg} / \mathrm{L}$ Setelah $24 \mathrm{Jam}$ Di Kelurahan Turikale Kecamatan Turikale Kabupaten Maros Tahun 2021

\begin{tabular}{cccccccc}
\hline No. & Perlakuan & $\begin{array}{c}\text { Jumlah } \\
\text { Jentik }\end{array}$ & $\begin{array}{c}\text { Jumlah } \\
\text { Kematian }\end{array}$ & $\begin{array}{c}\% \\
\text { Kematian } \\
\text { Jentik }\end{array}$ & $\begin{array}{c}\text { Suhu } \\
\left({ }^{\circ} \mathrm{C}\right)\end{array}$ & $\mathrm{pH}$ & $\begin{array}{c}\text { Status } \\
\text { Uji }\end{array}$ \\
\hline 1 & Kontrol & 20 & 0 & 0 & 29 & 7,0 & Rentan \\
2 & R.1-8.JM-1 & 20 & 4 & 20 & 29 & 7,0 & Rentan \\
3 & R.1-8.JM-2 & 20 & 7 & 35 & 29 & 7,0 & Rentan \\
4 & R.1-8.JM-3 & 20 & 9 & 45 & 29 & 7,0 & Rentan \\
5 & R.2-8.JM-1 & 20 & 3 & 15 & 29 & 7,0 & Rentan \\
6 & R.2-8.JM-2 & 20 & 8 & 40 & 29 & 7,0 & Rentan \\
7 & R.2-8.JM-3 & 20 & 9 & 45 & 28 & 7,0 & Rentan \\
8 & R.3-8.JM-1 & 20 & 3 & 15 & 29 & 7,0 & Rentan \\
9 & R.3-8.JM-2 & 20 & 8 & 40 & 29 & 7,0 & Rentan \\
10 & R.3-8.JM-3 & 20 & 9 & 45 & 29 & 7,0 & Rentan \\
\hline
\end{tabular}

Sumber : Juli 2021 
Jurnal Sulolipu : Media Komunikasi Sivitas Akademika dan Masyarakat

Vol. 21 No.2 2021

e-issn : 2622-6960, p-issn : 0854-624X

Tabel 3 Hasil Uji Resistensi Larva Aedes aegyptiSp Terhadap Penggunaan Temephos 0,02 mg/L Setelah 24 Jam Di Kelurahan Turikale Kecamatan Turikale Kabupaten Maros Tahun 2021

\begin{tabular}{clcccccc}
\hline No. & Perlakuan & $\begin{array}{c}\text { Jumlah } \\
\text { Jentik }\end{array}$ & $\begin{array}{c}\text { Jumlah } \\
\text { Kematian }\end{array}$ & $\begin{array}{c}\% \\
\text { Kematian } \\
\text { Jentik }\end{array}$ & $\begin{array}{c}\text { Suhu } \\
\left({ }^{\circ} \mathrm{C}\right)\end{array}$ & $\mathrm{pH}$ & $\begin{array}{c}\text { Status } \\
\text { Uji }\end{array}$ \\
\hline 1 & Kontrol & 20 & 0 & 0 & 29 & 7,0 & Rentan \\
2 & R.1-8.JM-1 & 20 & 5 & 25 & 29 & 7,0 & Rentan \\
3 & R.1-8.JM-2 & 20 & 8 & 40 & 29 & 7,0 & Rentan \\
4 & R.1-8.JM-3 & 20 & 7 & 35 & 29 & 7,0 & Rentan \\
5 & R.2-8.JM-1 & 20 & 2 & 10 & 29 & 7,0 & Rentan \\
6 & R.2-8.JM-2 & 20 & 9 & 45 & 29 & 7,0 & Rentan \\
7 & R.2-8.JM-3 & 20 & 9 & 45 & 28 & 7,0 & Rentan \\
8 & R.3-8.JM-1 & 20 & 7 & 35 & 29 & 7,0 & Rentan \\
9 & R.3-8.JM-2 & 20 & 6 & 30 & 29 & 7,0 & Rentan \\
10 & R.3-8.JM-3 & 20 & 7 & 35 & 29 & 7,0 & Rentan \\
\hline
\end{tabular}

Sumber : Juli 2021

Tabel 4.4 Hasil Uji Resistensi Larva Aedes aegyptiSp Terhadap Penggunaan Temephos $0,03 \mathrm{mg} / \mathrm{L}$ Setelah $24 \mathrm{Jam}$ Di Kelurahan Turikale Kecamatan Turikale Kabupaten Maros Tahun 2021.

\begin{tabular}{cccccccc}
\hline No. & Perlakuan & $\begin{array}{c}\text { Jumlah } \\
\text { Jentik }\end{array}$ & $\begin{array}{c}\text { Jumlah } \\
\text { Kematian }\end{array}$ & $\begin{array}{c}\% \\
\text { Kematian } \\
\text { Jentik }\end{array}$ & $\begin{array}{c}\text { Suhu } \\
\left({ }^{\circ} \mathrm{C}\right)\end{array}$ & $\mathrm{pH}$ & $\begin{array}{c}\text { Status } \\
\text { Uji }\end{array}$ \\
\hline 1 & Kontrol & 20 & 0 & 0 & 29 & 7,0 & Rentan \\
2 & R.1-8.JM-1 & 20 & 2 & 10 & 29 & 7,0 & Rentan \\
3 & R.1-8.JM-2 & 20 & 9 & 45 & 29 & 7,0 & Rentan \\
4 & R.1-8.JM-3 & 20 & 9 & 45 & 29 & 7,0 & Rentan \\
5 & R.2-8.JM-1 & 20 & 6 & 30 & 29 & 7,0 & Rentan \\
6 & R.2-8.JM-2 & 20 & 8 & 40 & 29 & 7,0 & Rentan \\
7 & R.2-8.JM-3 & 20 & 6 & 30 & 28 & 7,0 & Rentan \\
8 & R.3-8.JM-1 & 20 & 6 & 30 & 29 & 7,0 & Rentan \\
9 & R.3-8.JM-2 & 20 & 6 & 30 & 29 & 7,0 & Rentan \\
10 & R.3-8.JM-3 & 20 & 8 & 40 & 29 & 7,0 & Rentan \\
\hline
\end{tabular}

Sumber : Juli 2021 